\title{
The Uncanniness of the Death Instinct in "Bartleby"
}

\author{
Tianyu Ma
}

\begin{abstract}
This paper examines Herman Melville's "Bartleby, the Scrivener" alongside Sigmund Freud's "The 'Uncanny", and "Beyond the Pleasure Principle." It argues that Melville's title character is uncanny due to his exemplification of the universal death instinct. Throughout the story, the narrator represses his recognition of Bartleby's humanity and tries to keep him hidden, and these actions indicate a denial of the developing pseudo-paternalistic relationship between himself and the scrivener. Such a relationship is a corruption of Freud's "double," the central mechanism of his model of reproduction. This mechanism is driven by the sexual instinct that Bartleby clearly lacks, and in its absence he manifests the universal death instinct, as exemplified in his repetitive responses of "I would prefer not to," which ultimately leads him to his inevitable death.
\end{abstract}

Index Terms-Death instinct, double, uncanny.

\section{INTRODUCTION}

First published in 1853, Herman Melville's "Bartleby, the Scrivener: A Story of Wall Street" has since become a widely canonized work of American short fiction, and perplexed generations of readers with its peculiar and enigmatic title character. While it is easily perceptible from the very beginning that there is something off about Bartleby, it is more difficult to pinpoint what exactly makes him seem so strange. Many scholars have approached the text by attempting the psychoanalyze Bartleby or the narrator through whom his story is told. Norman Springer views the narrator as someone who lives comfortably within a set of limitations, which include the knowledge that humans are incapable of infinite pity, and contrasts him with Bartleby, who is likewise aware of the limits of human compassion, and chooses to remove himself from a world where such constraints are insurmountable [1]. Daniel Stempel and Bruce M. Stillians examine the two characters through the lens of Schopenhauer's philosophy of pessimism, and argue that Bartleby is a Schopenhauerian saint who has extinguished his will to live, whereas the narrator is torn between his characteristic prudence and belief in order, and the realization that Bartleby's suffering is shared by all of humanity [2]. James W. Mathews argues that the four adult characters in the narrator's office are characterized by the Renaissance notion of the four humors: the narrator is phlegmatic, Turkey is sanguine, Nippers is choleric, and Bartleby suffers from "melancholy adust," from which he is already beyond the point of no return when he first meets the narrator [3]. Robert E. Abrams argues that Bartleby manifests the dream state, as

Manuscript received February 15, 2017; revised June 12, 2017.

Tianyu Ma is with Department of English, Washington University in St. Louis, USA (e-mail: mat@wustl.edu). demonstrated in his lack of self-vigilance against unpremeditated behaviors that is characteristic of waking consciousness, and for that reason appears unnerving [4]. Amit Pinchevski examines readings of Bartleby that diagnose him as autistic, and identifies in the incommunicability that he personifies a starting point for medical, literary and philosophical discourses on communication and its link with sociality [5]. These various readings, as well as other critical interpretations in a similar vein, demonstrate that there is much to be gained by reading Melville's story with an eye toward understanding the psychological states of the main characters.

This paper, similarly taking a psychoanalytic approach, will examine Melville's story in conjunction with Sigmund Freud's "The "Uncanny" and "Beyond the Pleasure Principle," and argue that Bartleby exhibits a quality of uncanniness that stems from his exemplification of the universal death instinct. By repressing recognition of Bartleby's humanity and keeping him hidden, the narrator attempts to deny his developing pseudo-paternalistic relationship with Bartleby, which constitutes a corruption of Freud's concept of the "double." The process of "doubling" is the core mechanism of Freud's model of reproduction, and is driven by the sexual instinct seeking eternal life, which Bartleby noticeably lacks. In its absence, the scrivener manifests the death instinct, as evidenced by his compulsive repetitions of "I would prefer not to," which leads him down an inevitable path to his own demise, ultimately convincing the narrator that the death instinct is universal among all of humanity.

\section{BARTLEBY'S UNCANNINESS}

In "The "Uncanny," Freud acknowledges two of the most common sources that inspire feelings of uncanniness: human-like automatons and death. Although critical of Jentsch's existing analysis of the uncanny, Freud agrees with his statement that the writer of a story can create an uncanny effect by leaving "the reader in uncertainty whether a particular figure in the story is a human being or an automaton" [6] (132). He also observes that "many people experience the feeling [of uncanniness] in the highest degree in relation to death and dead bodies, to the return of the dead, and to spirits and ghosts" [6] (149). These two sources alone can account for much of what makes Bartleby uncanny, as the narrator in Melville's story repeatedly ascribes to him qualities of a machine, a ghost, or a dead body. One of the narrator's first descriptions of Bartleby is of him writing at his desk "silently, palely, mechanically" [7] (18) - characteristics that seem innocuous at first, but are later imbued with great significance. The mechanical quality in Bartleby quickly becomes exaggerated, manifesting itself in his automatic responses of "I would prefer not to" to the 
narrator's requests. Despite this habit, however, the narrator initially still considers Bartleby a "valuable acquisition" due to "his steadiness, his freedom from all dissipation, his incessant industry [..], his great stillness, his unalterableness of demeanor under all circumstances" [7] (84). All of these descriptions could be applied to a piece of productive machinery, and suggest that the narrator is tempted to see Bartleby as mechanical in an almost literal sense. Bartleby's silence and pale complexion likewise acquire new meaning when they become associated with death. When the narrator tries to summon Bartleby for an errand, he observes that "Like a very ghost, agreeably to the laws of magical invocation, at the third summons, he appeared at the entrance of his hermitage" [7] (79). Later, he goes from comparing Bartleby to a ghost to actually calling him one: "what does conscience say I should do with this man, or rather ghost," he ponders [7] (171). He also describes Bartleby as "cadaverous" on multiple occasions [7] $(87,155)$, and refers to his habit of standing in front of the window, looking out at the "dead brick wall" on the other side as his "dead-wall reveries" [7] (92). In these descriptions, Bartleby's appearance and demeanor become signs of lifelessness. Even though his actual state as a living human is never in doubt, his resemblance with automatons, ghosts and dead bodies is close enough for the narrator to feel "disconcerted" [7] (35), and as such characterizes the narrator's impression of the scrivener.

Were these observed resemblances entirely representative of how the narrator views Bartleby, one might conclude that they are the only reason why Bartleby appears uncanny. In actuality, however, they are complicated by seemingly contradictory instances in which the narrator sees Bartleby as decidedly human. Upon discovering that Bartleby has been living in the office, the narrator remarks, "The bond of a common humanity now drew me irresistibly to gloom. A fraternal melancholy! For both I and Bartleby were sons of Adam" [7] (89). Nevertheless, he resolves to dismiss Bartleby; however, when it comes time for him to carry out the decision, he is unable to do so because "I strangely felt something superstitious knocking at my heart, [...] denouncing me for a villain if I dared to breathe one bitter word against this forlornest of mankind" [7] (109). Amidst recurring comparisons of Bartleby to machines and ghosts, such explicit assertions of his humanity stand out as uncharacteristic, and suggest it is overly simplistic to say that the narrator views Bartleby as entirely inanimate and lifeless. The ending of the story attempts to reconcile the two opposed characterizations with the rumor that Bartleby once worked in a dead letter office: the narrator remarks that "On errands of life, these letters speed to death" [7] (250), and seems to suggest that such is the state of all human existence with the final exclamation, "Ah Bartleby! Ah humanity!" [7] (251). This rushed moralistic conclusion, however, feels inadequate as the sole resolution to a contradiction between Bartleby's humanity and lifeless qualities that has persisted throughout most of the story.

\section{REPRESSING BARTLEBY'S HUMANITY}

A different interpretation of the contradiction that is perhaps more satisfying can be found by applying Freud's theory of repression in the creation of the uncanny effect. Freud observes an overlap in the meanings of the German words unheimliche (of which "uncanny" is an English translation) and its opposite heimliche, and argues that the coinciding of meaning can be explained by the fact that the uncanny "is in reality nothing new or foreign, but something familiar and old-established in the mind that has been estranged only by the process of repression" [6] (148). In "Bartleby," the theory provides an explanation for the actions of the narrator, who, by seeing the scrivener as lifeless, appears to be repressing the urge to recognize Bartleby's humanity. When Bartleby refuses one of the narrator's requests for the first time, the narrator's reaction is described as follows:

I looked at him steadfastly. His face was leanly composed; his gray eye dimly calm. Not a wrinkle of agitation rippled him. Had there been the least uneasiness, anger, impatience or impertinence in his manner; in other words, had there been any thing ordinarily human about him, doubtless I should have violently dismissed him from the premises. But as it was, I should have as soon thought of turning my pale plaster-of-paris bust of Cicero out of doors. [7] (25)

Bartleby's composure, which leads the narrator to compare him to an inanimate object, prevents the narrator from reacting to the scrivener's insolence as he would to an "ordinary" human being in a similar situation. Thus, from the beginning Bartleby's automaton-like qualities are seen to suppress his humanity in the eyes of the narrator. Throughout the story, the writer constantly contemplates firing Bartleby or otherwise giving him less accommodation for his refusal to work, but for a long time does not actually carry out any such plans. In an aforementioned instance he is stopped by "something superstitious knocking at my heart" [7] (109); in another he decides that it is "prudent to check myself at present from further demonstrations" [7] (164). In light of Freud's theory of repression, the narrator's constant refusal to respond to Bartleby as if he were a regular human seems to indicate a denial of Bartleby's humanity in the narrator's mind.

If that is the case, then it is not surprising that the few moments in which the narrator does recognize Bartleby's humanity occur when the former is emotionally agitated. The discovery that Bartleby was living in the office engenders in the narrator "a feeling of overpowering stinging melancholy," and perhaps because the wave of emotion causes him to temporarily drop his guard, he begins to contemplate the "bond of a common humanity" between himself and Bartleby [7] (89). He quickly regains his composure, however, dismissing his thoughts as "chimeras, no doubt, of a sick and silly brain" [7] (89), and the pity that he initially felt for Bartleby disappears as he observes "that up to a certain point the thought or sight of misery enlists out best affections; but, in certain special cases, beyond that point it does not" [7] (93). Similarly, in his last meeting with Bartleby before the scrivener is sent to the Tombs, the narrator makes the offer to let Bartleby stay at his home in an emotional state of mind: "for the first time in all my exasperating connection with him [I was] fairly flying into a passion" [7] (210). When Bartleby refuses, the narrator quickly runs away, "effectively dodging every one by the 
suddenness and rapidity of my flight" [7] (213). While part of his motivation for escaping is no doubt to evade the crowd that wants to hold him accountable for Bartleby, the action may also serve as a mechanism for denying any further recognition of Bartleby's humanity that the narrator's agitated state might lead him to concede. The suppression of emotion directed at Bartleby is even more apparent in a previous scene at the business, in which Nippers enters the narrator's office reacting angrily to one of Bartleby's routine refusals to perform his job [7] (111112). The narrator tells Nippers to withdraw from the office, but nevertheless is himself affected by the latter's outburst, as when Turkey subsequently enters, the narrator observes: "“I would prefer to be left alone here," said Bartleby, as if offended at being mobbed in his privacy" [7] (120). While Bartleby's response is no different from any of his other mechanical objections to various tasks and suggestions, the narrator ascribes to it human feeling and motivation, suggesting that his own mind state has been influenced by Nippers' display of emotion - which would explain why he is so quick to instruct Nippers to leave.

This last example, in which the narrator enforces Bartleby's separation from the other scriveners by the folding-doors between the two offices, is emblematic of a constant desire by the narrator to keep Bartleby hidden. When the scrivener first arrives, the narrator places his desk in a corner of the office behind a green folding screen, "which might entirely isolate Bartleby from my sight, though not remove him from my voice" [7] (17). Despite Bartleby's eccentricities, the narrator eventually becomes accustomed to, and comes to accept, his quiet, unseen presence in the office: "you are harmless and noiseless as any of these old chairs; in short, I never feel so private as when I know you are here," he thinks to himself [7] (167). His tolerant attitude, however, changes when he begins to receive "unsolicited and uncharitable remarks" from professional friends who visit his office and are "struck by the peculiar aspect of the unaccountable Bartleby," and he ultimately decides to rid himself of the scrivener by moving out of his office [7] (168). The sudden change in the narrator's approach to Bartleby, after having put up with him for a surprisingly long period of time, suggests that it is somehow unacceptable to the narrator for other people to know about Bartleby's existence, and link him to the narrator himself. His later reaction to the news that Bartleby has been removed to the Tombs leads to a similar conclusion: "At first I was indignant; but at last almost approved. [...][A]s a last resort, under such peculiar circumstances, it seemed the only plan" [7] (214). Locked up in prison, Bartleby can now remain concealed from the public eye, a solution that the narrator finds satisfactory. The narrator's obsessive desire to keep Bartleby hidden may add to the sense of the uncanny attached to the scrivener: as Freud notes, Schelling claims that "everything is uncanny that ought to have remained hidden and secret, and yet comes to light" [6] (130). For instance, epilepsy and madness have an uncanny effect as "the ordinary person sees in them the workings of forces hitherto unsuspected in his fellow-man but which at the same time he is dimly aware of in a remote corner of his own being" [6] (151). Perhaps the narrator, in a position similar to that of an ordinary person disturbed by the uncanniness of mental illness, feels the need to keep Bartleby concealed because he is unwilling to confront the inner workings of his relationship with Bartleby.

\section{BARTLEBY AS "DOUBLE"}

The exact nature of that relationship, as well as how it relates to why the narrator represses Bartleby's humanity and seeks to conceal him, may be explained using Freud's concept of the "double." Freud notes that in the stories of Hoffmann, there is often a transferring of "mental processes from the one person to the other - what we would call telepathy - so that the one possesses knowledge, feeling and experience in common with the other, identifies himself with another person, so that his self becomes confounded, or the foreign self is substituted for his own" [6] (141). This process, which Freud summarizes as "doubling, dividing and interchanging the self" [6] (141), does not occur in its most literal sense in "Bartleby," which contains no mention of telepathy or other supernatural elements. A certain kind of mental transfer does take place, however, as the narrator and the other two scriveners pick up from Bartleby the habit of using the word "prefer" in their everyday conversation. The narrator observes that "somehow, of late I had got into the way of involuntarily using this word 'prefer' upon all sorts of not exactly suitable occasions," and expresses fear at this recent development: "I trembled to think that my contact with the scrivener had already and seriously affected me in a mental way" [7] (115). Thus, it appears that Bartleby and the narrator have, in a sense, started to become "doubles" of one another, and this relationship (or at least its recognition) is something that the narrator resists.

Specifically, the narrator's developing relationship with Bartleby can be described as paternalistic. For most of the story, the narrator provides Bartleby with a place to live and a wage for doing nothing, and patiently puts up with the scrivener's eccentric behavior. At one point he even decides that "my mission in this world, Bartleby, is to furnish you with office-room for such period as you may see fit to remain" [7] (167). His dynamic with Bartleby is very much like that of a parent and a child; however, the narrator is strongly resistant to recognizing that relationship or allowing it to continue to develop. The final concern that he considers before deciding to move out of the office is the possibility that Bartleby will "in the end perhaps outlive me, and claim possession of my office by right of his perpetual occupancy" [7] (169). Such a scenario would in effect make Bartleby his actual son for the purposes of inheritance (as well as his "double" who will occupy his former position in the office after his death), and the narrator, when forced to confront the potential consequences of his relationship with Bartleby in such concrete terms, finds a further continuation of the relationship unacceptable. This attitude may be the motivation behind the narrator's later response to a lawyer who seeks out his new quarters and claims that he is responsible for Bartleby: "the man you allude to is nothing to me - he is no relation or apprentice of mine" [7] (181). Having rid himself of Bartleby with much difficulty, the narrator is quick to dismiss any possibility of re-establishing a parental relationship with the scrivener. The rejection of 
this relationship could also account for why the narrator seeks to repress Bartleby's humanity - as one cannot be the parent of an inanimate object - as well as why he tries to keep Bartleby hidden - he is unwilling to recognize (or allow the public to recognize) that in many respects a parental dynamic has already been established. For all his generosity toward Bartleby, the narrator has no intention to adopt him as a son, and yet their relationship comes close to reaching that point. The unwelcome parent-child dynamic that is thus set up constitutes a corruption of the "double," which "has become a vision of terror, just as after the fall of their religion the gods took on daemonic shapes" [6] (143), and attaches to Bartleby a quality of uncanniness.

\section{DOUBLING AND REPRODUCTION}

This reading interprets the initial form of Freud's "double" as a parent-child relationship, and in turn can inform an examination of Freud's own discussion of the concept. He claims that the "double" which has come to wield an uncanny effect as the "ghastly harbinger of death" was initially intended to serve the opposite purpose, as "an insurance against destruction of the ego, and 'energetic denial of the power of death" [6] (141). While these terms may seem vague and impenetrable, Freud's subsequent mention of the "invention of doubling as a preservation against extinction" [6] (141), in light of the previous analysis of "Bartleby," seems like a highly apt description of biological reproduction. Freud then goes on to argue that "all those unfulfilled but possible futures to which we still like to cling in phantasy" are also "incorporated in the idea of a double" [6] (142). Within the family, this component of the "double" takes the form of parents projecting their own aspirations onto their children, or trying to provide conditions allowing their children to live out the lives that they sought but never achieved. It is not surprising, then, that when the "double," having originated from a most intimate and essential human relationship, is perceived outside of that context, it becomes unfamiliar, terrifying, and uncanny.

While Freud introduces the idea of the double in order to illustrate how it contributes to the effect of uncanniness, he does not go into detail in his discussion of the concept itself, or its relation to the preservation of life. As such, although the interpretation of doubling as reproduction fits nicely into the reading of "Bartleby" thus far, it is difficult to justify this interpretation solely on the basis of Freud's brief remarks on the subject in "The Uncanny." At this point, it may be useful to consult one his other works, in which he explores the topic of reproduction at length. In "Beyond the Pleasure Principle," Freud describes the process of reproduction in terms reminiscent of his discussion of the double in "The Uncanny." He notes that while most cells that make up higher-level organisms like plants and animals have a limited lifespan that must eventually culminate in death inside the organism, reproductive cells are different in that they "probably retain the original structure of the living substance, and, after a given time, detach themselves from the parent organism" and are able to exist independently [8] (5.10). Under the right conditions, these cells then begin to engage in the process of reproduction:
[T] hey begin to develop, that is, to repeat the same cycle to which they owe their origin, the end being that again one portion of the substance carries through its development to a finish, while another part, as a new germinal core, again harks back to the beginning of the development. Thus these reproductive cells operate against the death of the living substance and are able to win for it what must seem to us to be potential immortality [...]. [8] (5.10)

Freud's description of the process emphasizes its continuity: rather than creating generations of new organisms, it allows the parent organism, whose genetic information is retained in the reproductive cell, to prolong its lifespan beyond the death of its own body. Under this model of reproduction, each generation is essentially a "double" of the previous one. Freud then proceeds to trace sexual reproduction in higher-level organisms down the evolutionary tree to its predecessor - reproduction in simple unicellular forms of life - and demonstrates that this process is similarly achieved through "doubling" of the parent organism, in a more literal sense of the word. He cites an experiment by Woodruff on a culture of ciliated infusorium, a microorganism that "reproduces itself by division into two individuals" [8] (6.9). After each division, Woodruff isolated one of the individuals in fresh nutrient fluid, and when he ended the experiment at the $3,029^{\text {th }}$ generation, he observed that "the last descendant of the first slipperanimalcule was just as lively as its original ancestor, without any sign of age or degeneration" [8] (6.9). Freud comments on this result: "if such numbers are convincing, the immortality of protozoa seemed thus experimentally demonstrable" [8] (6.9). On a larger scale, the results of the experiment also have ramifications on the mechanism of reproduction in general. If they are indeed convincing, they suggest that reproduction, from its beginnings in unicellular organisms, has always been a process of doubling (whether in the form of one cell splitting into two, or a sex cell developing into another organism) that gives the parent organism the potential for eternal life through successive generations of its doubles.

\section{THE SEXUAL AND DEATH Instincts}

An important caveat in this model of reproduction is that in order for the cells involved to be immune to the effects of aging, they must be exposed to what Freud describes as an "invigorating influence" [8] (6.11). In protozoa that reproduce sexually, the conjugation of two cells followed by separation (which, according to Freud, "is doubtless the prototype of sexual propagation of higher organisms" [8] (6.11)) has a rejuvenating effect. In Woodruff's experiment on infusoria, placing each generation in fresh nutrient fluid provided the necessary invigoration, as when Woodruff and other researchers did not include this procedure, they observed signs of aging in later generations. Based on their findings, Freud concludes that "left to itself, the infusorium dies a natural death from the imperfect disposal of its own metabolic products: perhaps all higher animals die ultimately from the same inability" [8] (6.12). Indeed, in all of the examples that he has shown, the preservation of life requires some form of external stimulus, without which the 
organism can only head toward its own inevitable demise. Yet in "Bartleby," the title character is marked precisely by his resistance to any kind of invigorating influence. Once he begins working for the narrator, he is never seen absent from the office: as the narrator observes, "he never went to dinner; indeed [...] he never went any where. As yet I had never of my personal knowledge known him to be outside of my office. He was a perpetual sentry in the corner" [7] (51). When Bartleby still refuses to leave the premises of the office after the narrator has moved out, the latter suggests that the scrivener try a different job for a change of scenery, arguing that doing so "would improve your health" [7] (206), but Bartleby replies that "I like to be stationary" [7] (209), and "at present I would prefer not to make any change at all" [7] (212). From the perspective of Freud's model of reproduction, Bartleby's deteriorating health is likely a direct result of his confinement, while his refusal to improve his health through the rejuvenating effects of a fresh environment suggests a lack of the sexual instinct that aims for the preservation of life. In its absence, the sickly, cadaverous Bartleby exhibits only the opposite instinct, which seeks as its ultimate goal the natural end of death. To witness such a condition in any individual would be unpleasant; for the narrator to have to see it every day in an unwanted double brings the death instinct that he embodies much too close for comfort.

Bartleby's affinity to the death instinct is apparent in his most characteristic trait - his repeated responses of "I would prefer not to" to the narrator's requests - which can be read as driven by the repetition compulsion, a symptom of this instinct. In "Beyond the Pleasure Principle," Freud begins his discussion of the repetition compulsion with an observation of its manifestation in a child of eighteen months. He describes a game that the child plays with his mother:

Occasionally, however, this well-behaved child evinced the troublesome habit of flinging into the corner of the room or under the bed all the little things he could lay his hands on, so that to gather up his toys was often no light task. He accompanied this by an expression of interest and gratification, emitting a loud long-drawn-out 'o-o-o-oh' which in the judgement of the mother (one that coincided with my own) was not an interjection but meant 'go away' (fort). I saw at last that this was a game, and that the child used all his toys only to play 'being gone' (fortsein) with them. [8] (2.6)

Looking at Freud's text alongside Melville's story, one could draw a parallel between the child's game and Bartleby's refusal of the narrator's requests. The direct result of the game, as Freud notes, is that the child "could let his mother go away without making any fuss" [8] (2.7). Similarly, while the narrator does react to Bartleby's refusals with displeasure, in the end he always has no choice but to leave the scrivener alone. Moreover, just as it is unclear what the child seeks to gain by causing his mother to leave - as Freud remarks, "The departure of the mother cannot possibly have been pleasant for the child, nor merely a matter of indifference" [8] (2.7) - Bartleby's exchanges with the narrator also seem to lack a clear motivation. While the obvious explanation is that Bartleby is simply expressing his preference to not work or change his current conditions of living, it remains a mystery why he must state each objection in the exact same form, or why this manner of response seems to be reserved exclusively for the narrator. It would thus seem that the scrivener's responses, like the child's game with his mother, are at least in part an obsessive repetition that cannot be explained in terms of an immediate purpose.

According to Freud, the purpose of the repetition compulsion lies in its regressive nature. In addition to noticing the urge to repeat past actions and experiences in children and adults alike, he also observes the repetition compulsion at work in the behavior of migratory animals that always return to the same place to give birth to their young, and in the growth of germ cells in animals, as each cell is "obliged to repeat in its development-although in a fleeting and curtailed fashion-the structures of all the forms from which the animal is descended, instead of hastening along the shortest path to its own final shape" [8] (5.5). These phenomena, he argues, demonstrate the existence of "a tendency innate in living organic matter impelling it towards the reinstatement of an earlier condition" [8] (5.4). Following this train of thought to its logical next step, he claims that if the instincts of organic life are regressive, then ultimate the goal of life cannot be "a state never hitherto reached;" on the contrary, "it must rather be an ancient starting point, which the living being left long ago, and to which it harks back again by all the circuitous paths of development" [8] (5.7). And since "the inanimate was there before the animate," the conclusion must be that "the goal of all life is death" [8] (5.7). In light of Freud's remarks, the narrator's habitual association of Bartleby with death and inanimate objects - precisely the states to which the regressive instinct seeks to return - takes on a deeper meaning, perhaps suggesting that the narrator subconsciously perceives the death instinct in Bartleby from the very beginning. Moreover, the scrivener's repetitions of "I would prefer not to" are also linked to the presence of this instinct, a further sign of its manifestation in Bartleby. In fact, at the most literal level, it is already evident without the aid of Freud's theories that Bartleby's repeated refusals to do various tasks do indeed lead to his death. His refusal to work forces the narrator to abandon him and leave the office, after which his refusal to vacate the premises eventually lands him in the Tombs, where he dies because he "[prefers] not to dine" [7] (235). Thus, Bartleby's life trajectory over the course of Melville's story is itself an affirmation of the link between the repetition compulsion and the death instinct.

\section{INEVITABILITY OF DEATH}

Also apparent in the course of events leading to Bartleby's death is that the influence of the death instinct cannot be prevented by external forces. Despite the narrator's mostly accommodating treatment of Bartleby, from allowing him to live in the office, to inviting him to stay at the narrator's own home, to paying the grub-man at the Tombs and instructing him to "give particular attention to my friend there; let him have the best dinner you can get [and] be as polite to him as possible" [7] (230), the death 
instinct in the end still manages to take its toll on the scrivener. In "Beyond the Pleasure Principle," Freud argues that the strength of all instincts in general, including the death instinct, can be explained by the location and function of the cortical layer in the human brain, which provides the capability for consciousness. He defines consciousness as the functioning of a system that yields in the process "perceptions of excitations coming from without and feelings (Empfindungen) of pleasure and 'pain' which can only be derived from within the psychic apparatus" [8] (4.2). As this function requires the system to receive information from both the outside world and the depths of the organism's own brain, Freud reasons that the system must "lie on the boundary between outer and inner, must face towards the outer world, and must envelop the other psychic systems" [8] (4.2). Such a conclusion, he notes, is consistent with the findings of cerebral anatomy, "which places the 'seat' of consciousness in the cortical layer, the outermost enveloping layer of the central organ" [8] (4.2). He then goes on to explore the properties of the cortical layer by first looking at its analogous structure in unicellular organisms the surface of the cell - from which embryology shows that the cortical layer evolved. He reasons that the surface must serve an essential protective function for the organism, as "this morsel of living substance floats about in an outer world which is charged with the most potent energies, and it would be destroyed by the operation of the stimuli proceeding from this world if it were not furnished with a protection against stimulation" [8] (4.6). He thus theorizes that as a result of its contact with external stimuli, the cell surface undergoes "lasting alteration to a certain depth" [8] (4.5), becoming a rind-like structure that is "in a measure inorganic," and which "operates as a special integument or membrane that keeps off the stimuli, i.e. makes it impossible for the energies of the outer world to act with more than a fragment of their intensity on the layers immediately below which have preserved their vitality" [8] (4.6). Yet while this barrier provides protection against external stimuli, in the case of the cortical layer there are also excitations that come from inside the brain. As the cortical layer is not shielded from inner excitations, they "acquire increased economic significance and frequently give rise to economic disturbances comparable to the traumatic neuroses" [8] (5.1), a condition that, as Freud explains earlier, can only be activated by external stimuli that are strong enough to cause an "extensive rupture" of the protective barrier [8] (4.11). Furthermore, he notes that "the most prolific sources of such inner excitations are the socalled instincts of the organism" [8] (5.1); thus, it is not surprising that the death-instinct, as an inner excitation that directly reaches the cortical layer, has such a strong effect on Bartleby.

In view of Freud's model of the structure of unicellular organisms, the narrator's preoccupation with housing Bartleby, while no doubt driven in part by a selfish desire to conceal him, is at the same time also an attempt to protect him from external stimuli. The narrator's office, for most of the story, acts as Bartleby's barrier from the outside world, much like a rigid cell wall surrounding the sensitive substance inside the cell. Just as the surface of a cell serves "the purpose of collecting information about the direction and nature of the external stimuli, and for that it must suffice to take little samples of the outer world, to taste it, so to speak, in small quantities" [8] (4.6), within the office the narrator reacts to Bartleby's refusal to work with disapproval, similarly to the rest of the world, but with only a fraction of its intensity. He takes care not to let Bartleby experience the full force of the outside world's objection to his behavior, asking Turkey and Nippers to leave and closing the office doors when they lash out at him in anger. After Bartleby is removed from the office, the prison walls within which he is placed serve a similar function, providing, as the narrator suggests to the officer at the Tombs, "as indulgent confinement as possible" away from the outside world [7] (217).

The narrator's attempts to shield Bartleby from outside forces represent just one aspect of a general tendency to attribute the scrivener's condition to external influences. After finding out that Bartleby eats only ginger nuts and nothing else, he considers "the probable effects upon the human constitution of living entirely on ginger-nuts" before finally concluding that such a diet could not explain the scrivener's behavior [7] (52). On another occasion, the narrator notices that Bartleby's eyes "looked dull and glazed," and it immediately occurs to him "that his unexampled diligence in copying by his dim window for the first few weeks of his stay with me might have temporarily impaired his vision" [7] (131). Thus he assumes that Bartleby's health is influenced primarily by his working conditions, a belief that is also apparent in his later suggestion to Bartleby to find another job in a different environment in order to improve his health. Yet while the link between Bartleby's confinement and deteriorating health is probably a valid one, it does not get at the heart of what drives Bartleby to remain confined and stationary, namely the death instinct, in the absence of a counterbalancing sexual instinct seeking invigoration. Likewise, the narrator's efforts to protect Bartleby with a barrier against external stimuli are bound to be fruitless, as they ignore the fact that the death instinct comes from within the organism. Indeed, in the end the narrator fails to protect Bartleby from the influence of his own death drive, which successfully claims its victim. The fact that it had to overcome external opposition on the way to its ultimate goal makes it all the more frightening, for it thus acquires a sense of inevitability, while the individual afflicted by it appears by comparison completely powerless.

\section{UNIVERSALITY OF THE DEATH INSTINCT}

To be sure, while the death instinct is unusually apparent in Bartleby, it is by no means limited to the scrivener himself. Going back to the passage where the narrator realizes that he and the other scriveners are picking up on the habit of using the word "prefer," it seems that the narrator is particularly disturbed by the undeliberate nature of the phenomenon. He remarks that he is "involuntarily using" [7] (115) the word, and likewise Nippers "did not in the least roguishly accent the word prefer. It was plain that it involuntarily rolled from his tongue" [7] (125). Turkey, too, is unaware that he is using the word, asking "What word, sir?" [7] (119) in response to the narrator's observation that 
"you have got the word too" [7] (118). Thus, within the span of a single conversation, the narrator witnesses himself and the other two scriveners repeatedly using the word "prefer" without any intent or coordination on their part. In "Beyond the Pleasure Principle," Freud explains that such involuntary repetitions of similar experiences have a highly disturbing (or, to use his word for describing the repetition compulsion, "daemonic" [8] (3.7)) character:

We are less astonished at this 'endless repetition of the same' if there is involved a question of active behaviour on the part of the person concerned, and if we detect in his character an unalterable trait which must always manifest itself in the repetition of identical experiences. Far more striking are those cases where the person seems to be experiencing something passively, without exerting any influence of his own, and yet always meets with the same fate over and over again. [8] (3.7)

In a similar vein, he also discusses the subject of "involuntary repetition" [6] (144) in "The 'Uncanny," and notes the uncanny nature of unexplainable coincidences:

For instance, we of course attach no importance to the event when we give up a coat and get a cloakroom ticket with the number, say, 62; or when we find that our cabin on board ship is numbered 62. But the impression is altered if two such events, each in itself indifferent, happen close together, if we come across the number 62 several times in a single day, or if we begin to notice that everything which has a number - addresses, hotel-rooms, compartments in railway-trains - always has the same one, or one which at least contains the same figures. We do feel this to be 'uncanny' [...]. [6] (144)

Evidently, the narrator and scriveners' uses of "prefer" are disconcerting because they occur in quick succession yet are seemingly spontaneous. At the same time, however, they are also different from a recurring number in that an explanation of their cause can be sought - after all, the word is uttered by living entities, even if the utterance is unintentional. In repeating Bartleby's characteristic word, a word which is always accompanied by a refusal to work that causes in them feelings of anger and exasperation rather than pleasure, the narrator and two other scriveners demonstrate that they too are affected by the repetition compulsion, in keeping with Freud's claim of its universality. To recognize the presence of this compulsion in themselves - and the narrator, voicing concern about his mental state and potential "further and deeper aberration" [7] (115) caused by contact with Bartleby, apparently does would be to also acknowledge that they possess the same death instinct that has plainly and disturbingly manifested itself before their eyes in Bartleby.

\section{CONCLUSION}

By the end of the story, the narrator seems to have accepted the idea of a universal death instinct. Regarding the rumor that Bartleby once worked at a dead letter office, he comments: "Conceive a man by nature and misfortune prone to a pallid hopelessness, can any business seem more fitted to heighten it than that of continually handling these dead letters and assorting them for the flames?" [7] (250). In contrast with his earlier habit of attributing the scrivener's condition to external factors, he notes that the job may have heightened Bartleby's "pallid hopelessness," but acknowledges that it is "nature and misfortune" that makes him prone to such a condition in the first place. Moreover, the narrator reads into the dead letter office a symbolic significance that pertains to more than just the scrivener himself. "Dead letters! does it not sound like dead men?" he exclaims, and in the context of this comparison his later remark, "On errands of life, these letters speed to death" [7] (250), is a description of the death instinct, which drives living things to return to an original state of death. The subsequent final line, "Ah Bartleby! Ah humanity!" [7] (251), which initially may have seemed out of place after the narrator has depicted Bartleby as distinctly not human for so long, can also be read in a new light as a recognition that this instinct is shared by all of humanity. Thus, to go back to Schelling's definition of the uncanny ("everything is uncanny that ought to have remained hidden and secret, and yet comes to light" [6] (130)), one might say that Bartleby has singlehandedly allowed such a grim view of human nature, which in view of its highly disturbing nature ought to have remained hidden, to come to light in a dramatic way. For that reason, it is inevitable that he should appear uncanny.

\section{ACKNOWLEDGMENT}

The author is grateful to Prof. Guinn Batten (Department of English, Washington University in St. Louis) for her advice in the formative stages of this paper.

\section{REFERENCES}

[1] Springer, Norman. "Bartleby and the terror of limitation," PMLA, vol. 80, no. 4, 1965, pp. 410-418.

[2] S. Daniel and B. M. Stillians, "Bartleby the scrivener: A parable of pessimism," Nineteenth-Century Fiction, vol. 27, no. 3, 1972, pp. 268-282.

[3] M. W. James, “'Bartleby': Melville's tragedy of humours," Interpretations, vol. 10, no. 1, 1978, pp. 41-48.

[4] A. E. Robert, "'Bartleby' and the fragile pageantry of the ego," $E L H$, vol. 45 , no. 3,1978 , pp. 488-500.

[5] P. Amit. "Bartleby's autism: Wandering along Incommunicability," Cultural Critique, vol. 78, 2011, pp. 27-59.

[6] Strachey, Alix, tr. Freud, Sigmund. "The 'Uncanny'," The Standard Edition of the Complete Psychological Works of Sigmund Freud. London: Vintage, 2001.

[7] M. Herman, "Bartleby, the scrivener: A story of wall-street," Bartleby.com. N.p., n.d. Web. 18 Oct. 2016.

[8] C. J. M. Hubback and F. Sigmund, "Beyond the pleasure principle,".

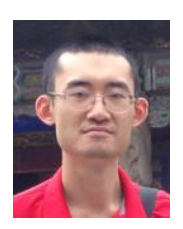

Tianyu Ma is a student at Washington University in St. Louis majoring in English literature (anticipated BA 2017). 